\title{
EXPERIMENTAL INVESTIGATION OF THE PERFORMANCE OF VCR DIESEL ENGINE FUELLED BY N-BUTANOL DIESEL BLEND
}

\author{
Nitin Goyal ${ }^{1}$, Ashish Nayyar ${ }^{2}$, Chandan Kumar ${ }^{3}$ \\ ${ }^{1}$ Mechanical Engineering Department, Swami Keshvanand Institute of Technology, Jaipur \\ ${ }^{2}$ Mechanical Engineering Department, Swami Keshvanand Institute of Technology, Jaipur \\ ${ }^{3}$ Mechanical Engineering Department, Swami Keshvanand Institute of Technology, Jaipur
}

\begin{abstract}
Increasing demand of fuel in everyday life and its hazards cause serious problem for this planet. Serious attention is required to see this problem. In this paper there is a research to find out the alternative for diesel fuel and efforts to increase its performance. $N$-butanol is blended with diesel in different volume (B5 - 5\% n-butanol and 95\% diesel, B10, B15, B20, B25 and B30) and its effects on various performance parameters are studied. Increasing Butanol concentration in fuel increases BSFC of the engine. Increasing butanol ratio reduces the BTE of the engine from $24 \%$ to $22 \%$ at maximum load. Exhaust gas temperature reduces with increasing butanol. Mechanical efficiency also increases with addition of $n$-butanol.
\end{abstract}

Keywords: N-butanol, BSFC, BTE

\section{INTRODUCTION}

The main purpose of this report is to investigate the performance and emission characteristics of the diesel engines (C.I. engine) using diesel fuels with additives. In this dissertation VCR diesel engine is fuelled with ButanolDiesel blends in different proportions.

Research interest in non- polluting and renewable fuel sources has developed due to rapidly increasing fuel cost, regularly decreasing the sources of conventional fuels and pollution in the environment. Maximum energy need of the world is fulfilled by the fossil fuels. Combustion of fossil fuels causes acid rains and air pollution in the cities. Continuous efforts have been made to replace these fossil fuels with renewable energy sources.

In terms of energy consumption India holds sixth rank in the world and is going to increase to third position by 2020 , with increasing rate of $6.8 \%$ per annum. In modern economy economic growth of any country depends on its energy resources and there utilization. Resources which are affordable, accessible and environment friendly decide the economic growth crucially. [1] [2]

C.I. engine or diesel engines used for agriculture, electricity generation, transportation and marine engine. These engines emit tones of major pollutants of the atmosphere every day, creating great health hazards and decreasing quality of air.

\subsection{Health Effects of Diesel Engine Emission}

Emission from diesel engine cause severe health effects. These effects include cardiovascular and pulmonary diseases and even cancer. In most places of the world, diesel engine exhaust is the major contributor of particulate matter. Chest diseases occur due to effects of very fine particles below $10 \mu \mathrm{m}$ on respiratory morbidity and mortality. Also there is eye and nasal irritation due to exposure to sufficient concentration of diesel fumes but there is no evidence of any permanent effect. There is a development of cough and sputum due to chronic inhalation of diesel fumes. Higher exposure to these diesel fumes leads us to the conjunctivae and upper respiratory tract that is nearly always reversible within few days. So these fumes affect the cardiovascular system and respiratory system.

\subsection{Additives}

To prepare blends with C.I. and diesel engines so many additives are readily available in the market. Oxygenated compounds are most widely used among various additives available, because availability of extra oxygen leads to better combustion and thus lowering emissions. Oxygen content of the additives and its molecular formula have influence on soot reduction. Blending of $10-20 \%$ volume of oxygenate chemicals with diesel fuels reduces soot formation. High Quantity of additives will alter chemical and physical properties such as: density, volatility, viscosity and cetane index, significantly.

Alcohols have an additional oxygen atom in their molecular structure. So, they are considered as oxygenated compounds. These oxygenated compounds after blending with diesel oil improve the performance via the increase of thermal energy output and combustion products alteration.

\subsection{Merits of Additives}

Following are the merits of additives:-

(a) Performance of the engine: Some additives can improve thermal efficiency up to $18 \%$ without affecting the torque. 
(b) Emission Reduction: With the help of diesel fuel additives pollutants and greenhouse gases reduces up to $50 \%$ or more.

\subsection{Demerits of additives}

Following are the demerits of additives:-

(a) Cost of fuel: Due to high cost of additives cost of diesel fuel additives blend increases.

(b) Preparation of blend: - Blending of diesel fuel with additives are difficult in many cases.

\section{5 n- Butanol}

Butanol or n-butyl alcohol or n-butanol is an alcohol having four carbons in its one molecule. Its chemical formula is $\mathrm{C}_{4} \mathrm{H}_{9} \mathrm{OH}$. Isomers of butanol include isobutanol, 2-butanol and tert-butanol. Butanol is a member of "fusel alcohols" (German word for bad liquor) group, alcohols which have good solubility in water and have more than two carbon atoms. It is present in many food and beverages and naturally occurs as a minor product of the fermentation of sugars and carbohydrates. It is used in fruit, rum, whisky, cream, butter, ices, ice cream, baked goods and cordials. It is also used as artificial flavorant in the United states. It is also used in a wide range of consumer products.

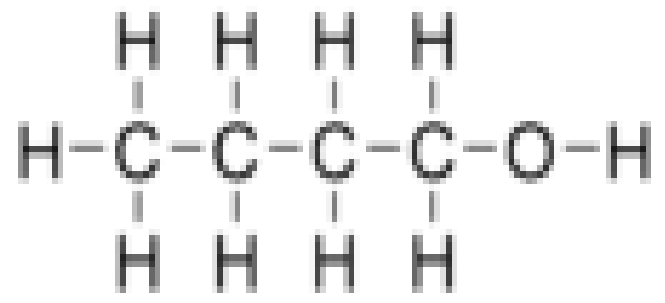

Fig. 1 Structure of n-Butanol

\subsection{Properties of Diesel and Additives}

There are some properties which are essential to check before use of additives with diesel fuel in the internal combustion engines. Table 1.1 gives the comparison between diesel and n-butanol physical and combustion properties.

Table 1.1 Comparison of key Physical and chemical properties between n-Butanol and Diesel

\begin{tabular}{|l|l|l|}
\hline & n-Butanol & Diesel \\
\hline Chemical Formula & $\mathrm{C}_{4} \mathrm{H}_{10} \mathrm{O}$ & $\mathrm{C}_{10} \mathrm{H}_{20} \mathrm{C}_{15} \mathrm{H}_{28}$ \\
\hline Molecular Weight $(\mathrm{g} / \mathrm{mole})$ & 74 & 170 \\
\hline Density $\left(\mathrm{kg} / \mathrm{m}^{3}\right)\left(15^{\circ} \mathrm{C}\right)$ & 0.811 & $0.820-0.845$ \\
\hline Boiling Point $\left({ }^{\circ} \mathrm{C}\right)$ & 117 & $180-370$ \\
\hline Flash Point $\left({ }^{\circ} \mathrm{C}\right)$ & 35 & $55-85$ \\
\hline Auto-ignition temperature $\left({ }^{\circ} \mathrm{C}\right)$ & 385 & $>250$ \\
\hline Lubricity $(\mu \mathrm{m})$ & 590 & 310 \\
\hline Lower heating value $(\mathrm{MJ} / \mathrm{kg})$ & 34.366 & 43.4 \\
\hline $\begin{array}{l}\text { Latent heat of vaporization } \\
(\mathrm{kJ} / \mathrm{kg})\end{array}$ & 0.581 & 0.27 \\
\hline Cetane Number & $<25$ & \\
\hline Viscosity $\left(40^{\circ} \mathrm{C}\right) \mathrm{cSt}$ & 2.5 & $40-55$ \\
\hline Oxygen Content $(\mathrm{wt} \%)$ & 21.6 & $2-3.5$ \\
\hline Carbon Content $(\mathrm{wt} \%)$ & 64.8 & 0 \\
\hline Hydrogen Content $(\mathrm{wt} \%)$ & 13.5 & $84-87$ \\
\hline Sulphur Content $(\mathrm{PPM})$ & 0 & $16-13$ \\
\hline
\end{tabular}

$\mathrm{N}-$ Butanol is a renewable biofuel, as it is less hydrophilic. Butanol has high cetane number, higher energy content, higher viscosity, lower vapor pressure, higher miscibility, higher flash point than ethanol, so it is more preferable in blending with diesel.

\section{EXPERIMENTAL SET-UP}

The realized engine test rig is shown in Fig.2. It consists of engine coupled with eddy current dynamometer, smoke meter, exhaust gas analyzer, control panel, computer system, thermocouples and various sensors to measure temperature at different parts of the engine. 


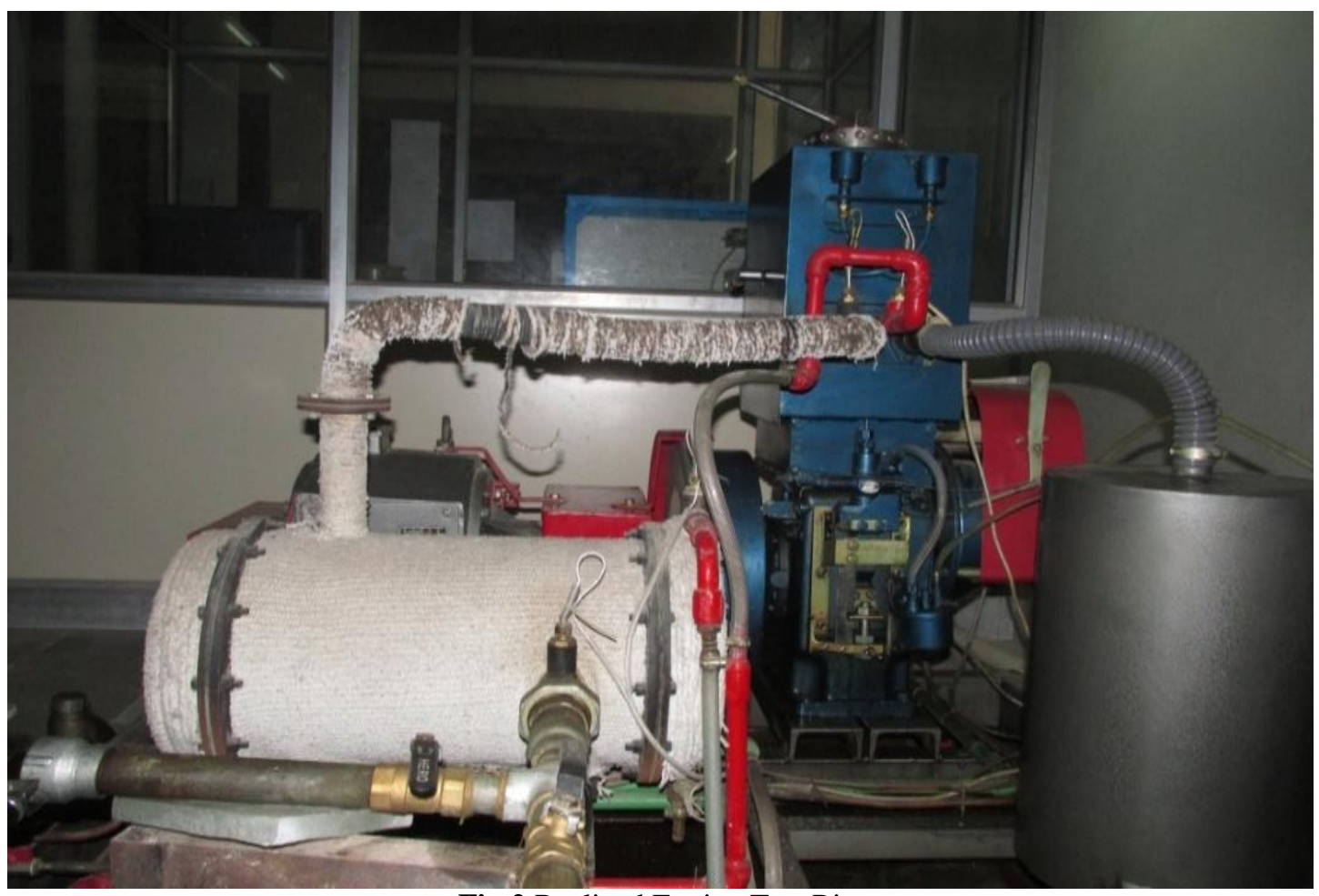

Fig.2 Realized Engine Test Rig

A single cylinder, four stroke, direct injection, water-cooled, vertical type, and naturally aspirated variable compression ratio engine is used for research study. This compact size test engine has been manufactured by Technical Teaching Equipment, Bangalore (India). Engine can start in both ways- by hand or by self start provided with centrifugal speed governor. Engine's compression ratio can be changed by changing the position of cylinder head up and down. Between cylinder and cylinder liner water jacket is provided.

Eddy current dynamometer is coupled with the engine using pipe coupling to measure the torque of the engine. Load applied on the engine is measured by using a strain gauge type load cell. Load can be varied on the engine with the help of a permanently interfaced computer and instrumentation set-up.

Exhaust gas has been measured by using i3sys exhaust gas analyzer (EPM1601). It is used to measure the following exhaust emissions from the engine, i.e. hydrocarbon (HC), carbon monoxide $(\mathrm{CO})$, carbon dioxide $\left(\mathrm{CO}_{2}\right)$, oxides of nitrogen $\left(\mathrm{NO}_{\mathrm{x}}\right)$, oxides of sulphur $\left(\mathrm{SO}_{\mathrm{x}}\right)$, and oxygen $\left(\mathrm{O}_{2}\right)$.

Exhaust smoke density and opacity has been measured by using AVL smoke meter. It is used to measure smoke opacity, absorption, rpm of an engine, and oil temperature.

Highly integrated $\mathrm{C}^{++}$language based software the Engine Test Express was used to collect, store and analyze the data. This software is reliable, quick and easy to operate. The post processing software has been developed in MS Excel and used for arranging and graphical representation of exported data.
All digital indicators (with digital display) and The PV-P $\theta$ converters (without displays) are grouped together and connected to one RS232 to RS485 converter whose RS232 output is connected to Comm1 port of the PC. Data acquired and calculation will be displayed in a tabular form and graphs can display by selecting from view of pc on line.

\section{CALCULATIONS}

\section{Brake Specific Fuel Consumption:}

$$
B S F C=\frac{m_{f}}{B \cdot P .}
$$

\section{Brake Thermal Efficiency:}

$$
\eta(B T E)=\frac{B . P . * 3600}{m_{f} \times C . V .}
$$

3. Mechanical Efficiency:

$$
\eta(\text { Mech })=\frac{B \cdot P .}{I \cdot P .}
$$

Where:-

B.P. = Brake power in $\mathrm{kW}$.

I.P. = Indicated power in $\mathrm{kW}$.

$\mathrm{m}_{\mathrm{f}}=$ Mass of fuel $(\mathrm{kg} / \mathrm{sec}$. $)$

C.V. = Calorific value $(\mathrm{kJ} / \mathrm{kg}$.)

4. Calorific Value $=$ Vol. of Diesel in $\%(\mathrm{~V} / \mathrm{V}) \times \mathrm{C}$.V.

+ Vol. of n-butanol in \% (V/V) 


\section{PERFORMANCE CHARACTERISTICS OF ENGINE:}

\subsection{Brake Specific Fuel Consumption}

The graph shown in Fig. 4.1 is drawn between brake specific fuel consumption (BSFC) and engine load. It was observed that BSFC decreases with increasing load. Generally n-butanol /diesel fuel blends consume more fuel than reference diesel fuel to generate the same engine output torque because fuel blend has lower heat content. All n-butanol/diesel fuel blends slightly increase the BSFC, this is because decrease energy content with increasing n-butanol content.

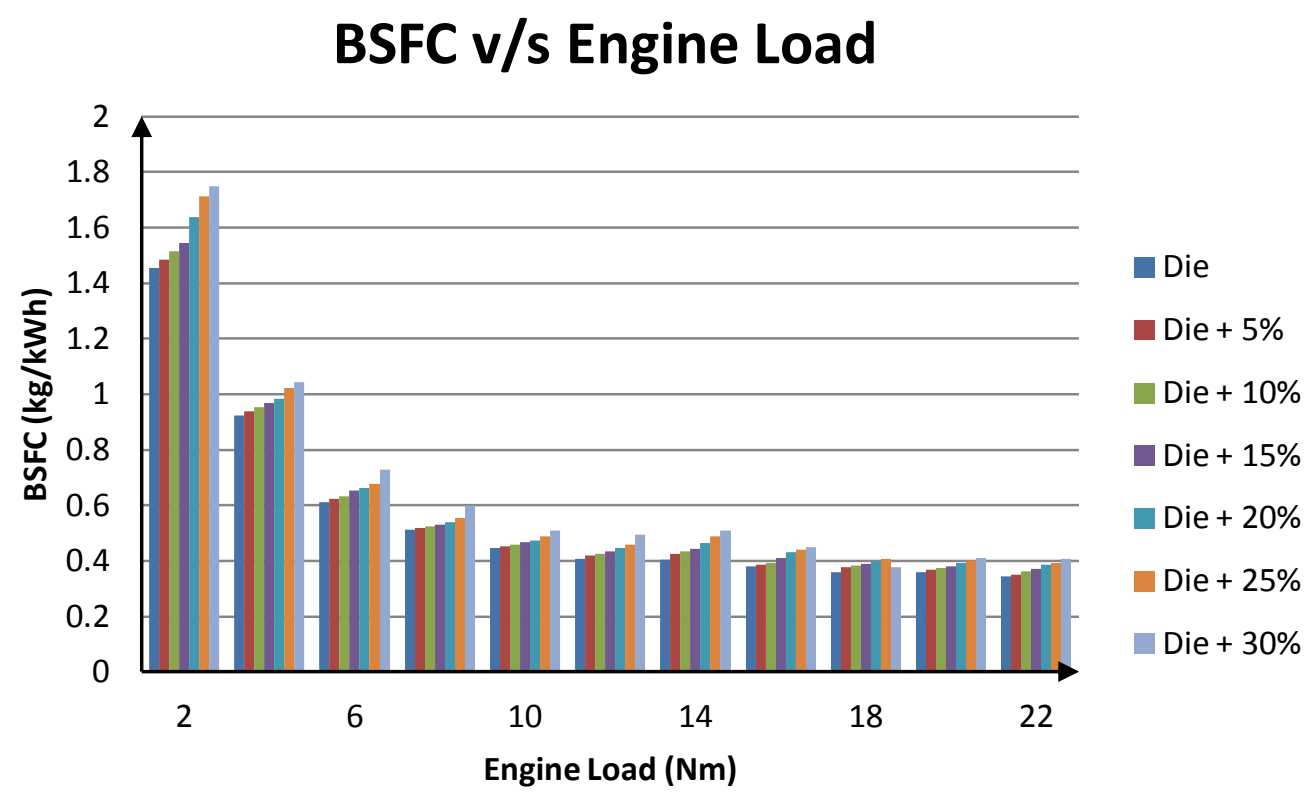

Fig.4. 1 Comparison of BSFC with Engine Load for different blends of n-butanol/diesel

\subsection{Brake Thermal Efficiency (BTE)}

The graph shown in Fig. 4.2 is drawn between Brake thermal efficiency (BTE) and engine load. BTE increases with increasing engine load. There is very slight decrease in BTE by using blends B5, B10, B15, B20, B25 and B30. Decrease in BTE due to significant decrease energy content and cetane number of fuel. Thus decrease in BTE results from combined effect of considerable decrease in break power and increase in fuel consumption.

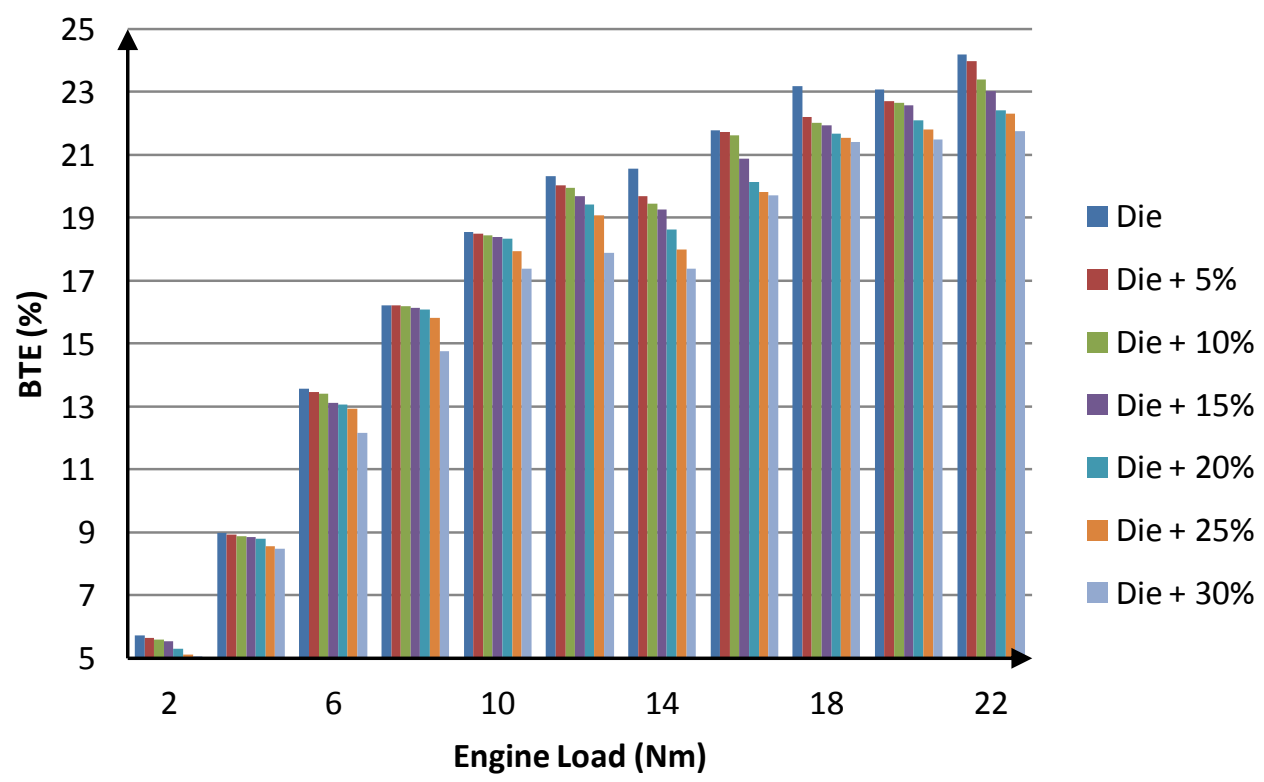

Fig.4. 2 Comparison of BTE with Engine Load for different blends of n-butanol/diesel 


\subsection{Exhaust Gas Temperature (EGT):}

The graph shown in Fig. 4.3 is drawn between exhaust gas temperature and engine load. As shown in figure exhaust gas temperature decreases with n-butanol diesel fuel blends. This may occur due to lower energy content, higher latent heat of vaporization and higher oxygen content of the fuel. N-butanol/diesel fuel blends supply more oxygen to combustion chamber which results in increasing the temperature of combustion chamber. Due to these conflicting factors, there is a decreasing effect on exhaust gas temperature on the variation of n-butanol content in the fuel blends.

\section{Exhaust Temprature v/s Engine Load}

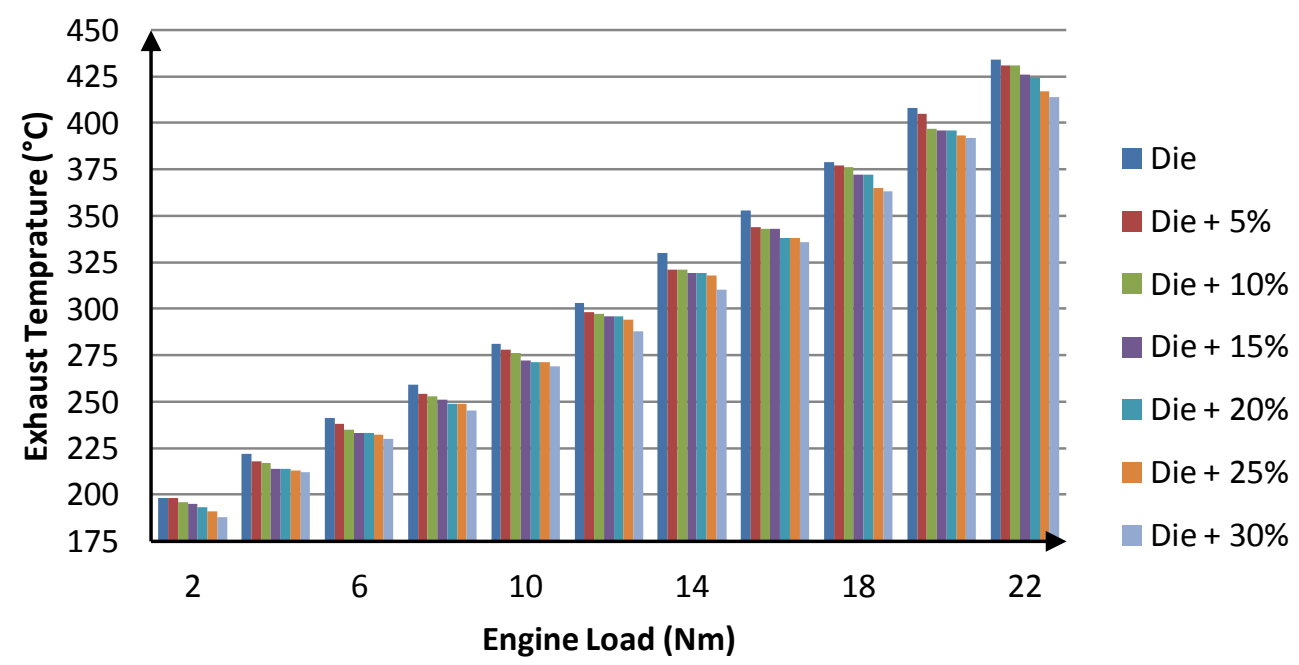

Fig.4. 3 Comparison of EGT with Engine Load for different blends of n-butanol/diesel

\subsection{Mechanical Efficiency:}

The graph Shown in Fig. 4.4 is drawn between mechanical efficiency and engine load. As shown in figure the mechanical efficiency increases with increasing n-butanol.

\section{Mechanical Efficiency v/s Engine Load}

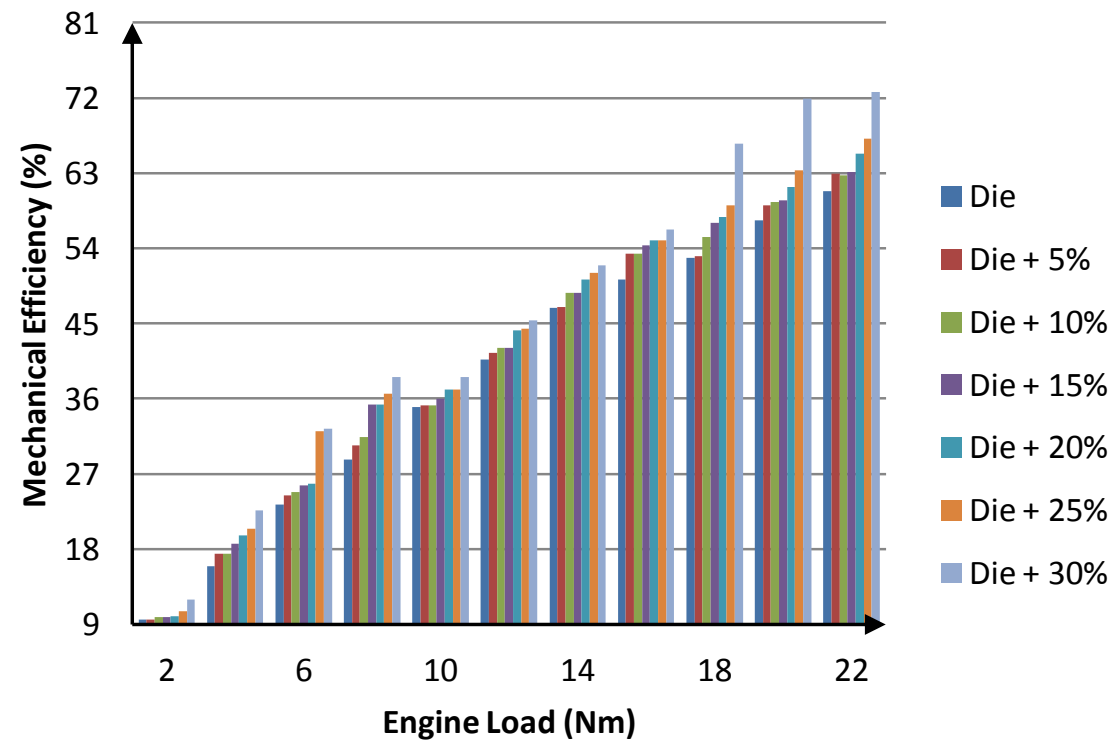

Fig.4. 4 Comparison of Mechanical Efficiency with Engine Load for different blends of n-butanol/diesel 


\section{CONCLUSION}

As we have discussed the various performance parameters of combustion ignition engine with the use of different blends of n-butanol and diesel fuel (B5, B10, B15, B20, B25, and B30). From this research work we concluded the following result.

- Brake Specific Fuel Consumption increases with increasing concentration of n-butanol which slightly reduces with increasing concentration of butanol.

- Brake thermal efficiency decreases with increasing ratio of n-butanol in the diesel blend. At maximum load BTE is maximum $24 \%$ which reduces to $22 \%$ with B30.

- Exhaust gas temperature decreases with increasing butanol ratio.

- Mechanical Efficiency increases with increasing butanol. Maximum increase noticed at full load.

\section{REFERENCES}

[1] "A Report working on Working Group on research and Development for the Energy Sector for the formulation of the Eleventh Five year plan (200707)," Planning Commision, 2006-07.

[2] "TERI, Energy Data Directory and Yearbook 2010/2011," Tata Energy Reaseach Institute, 2010/2011

[3] S. Gyanendra, "An Analytical Approch to Farm Mechanization in India-Agricultural Machinery Development and Promotion," Journal of Rural Devlopment, vol. 7(2), pp. 297-319, 1999.

[4] "Agricultural statistics at a Glance," Directorate of Economics and Statistics, Department of Agriculture and Cooperation, Ministry of Agriculture, Government of India,, 2001-2010.

[5] C. .-Y. Lin and J. .-C. Huang, "An oxegenating additive for improving the performance and emission characteristics of marine diesel engines," Ocean Engineering, pp. 1699-1715, 2003

[6] M. Guru, A. Koca, O. Can, C. Cinar, and F. Sahin, "Biodiesel production from waste chicken fat based sources and evaluation with $\mathrm{Mg}$ based additive in a diesel engine," Renewable Energy, vol. 35, no. 2010, pp. 637-643, 2010.

[7] S. B.Prajapati, P. P. Rathod, and N. K. Patel, "Performance and Emission Improvements of 4 Stroke Multi- Cylinder CI- Engine by Use of DMCEGM-Diesel Blends," International Journal of Advanced Engineering Research and Studies, vol. 1, no. 4, pp. 70-73, Jul. 2012.

[8] S. Naramsetty, v. R. Kumar, and y. V. H. Rao, "Performance and emission characteristics of Diesel Engine fuelled with biodiesel of Mahua oil \& Diesel Blends with Additives," International Journal of Engineering Reasearch and Applications, vol. 3, no. 4, pp. 936-941, Jul. 2013.

[9] G. Yanfeng, L. Shenghua, G. Hejun, H. Tiegang, and Z. Longbao, "A new diesel oxygenate additive and its effects on engine combustion and emissions," Applies Thermal Engineering, vol. 27, pp. 202-207, Jul. 2007.
[10] A. Keskin, M. Guru, and D. Altiparmak, "Influence of metallic based fuel additives on performance and exhaust emissions of diesel engine," Energy Conservation and Management, vol. 52, pp. 60-65, 2011.

[11] W. M. Yang, et al., "Impact of emulsion fuel with nano-organic additives on the performance of diesel engine," Applied Energy, vol. 112, pp. 1206-1212, Dec. 2013.

[12] S. D., V. T., and T. M., "Experimental analysis of Combustion and Emissions characteristics of $\mathrm{CI}$ Engine Powered with Diethyl Ether blended Diesel as fuel," Research journal of Engineering Sciences, vol. 1, no. 4, pp. 41-47, 2012.

[13] C. Cinar, O. Can, F. Sahin, and H. S. Yucesu, "Effects of premixed diethyl ether (DEE) on combustion and exhaust emissions in HCCI-DI diesel engine," Applied Thermal Engineering, vol. 30, pp. 360-365, 2010.

[14] Y. Wang, Y. Zhao, and Z. Yang, "Dimethyl Ether energy ratio effects in a dimethyl ether- diesel dual fuel premixed charge compression ignition engine," Applied Thermal Engineering, vol. 54, pp. 481-487, 2013.

[15] M. Natio, et al., "A comparative study on the autoxidation of dimethyl ether comparision with diethyl ether and diisopropyl," journal of loss prevention in the process industries, vol. 18, pp. 469473, 2005

[16] N. K. M. Joth, G. Nagarajan, and S. Reganarayanan, "LPG fueled diesel engine using diethyl ether with exhaust gas recirculation," International Journal of Thermal Sciences, vol. 47, pp. 450-457, 2008

[17] D. H. Qi, H. Chen, L. M. Geng, and Y. Z. Bian, "Effect of diethyl ether and ethanol additives on the combustion and emission characteristics of biodieseldiesel blended fuel engine," Renewable energy, vol. 36, pp. 1252-1258, 2011.

[18] L. Xing-Cai, Y. Jian-guang, Z. Wu-gao, and H. Zhen, "Effect of cetane number improver on heat release rate and emissions of high speed diesel engine fueled with ethanol-diesel blend fuel," Fuel, vol. 83, pp. 2013-2020, Jun. 2004.

[19] L. Ruina, W. Zhong, N. Peiyong, Z. Yang, and L. Lilin, "Effects of cetane nimber improvers on the performance of diesel engine fuelled with methanol/biodiesel blend," Fuel, vol. 128, pp. 180187, 2014.

[20] H. S. Yucesu, T. Topgul, and M. O. Can Cinar, "Effects of ethanol- gasoline blends on engine performance and exhaust emissions in different compresseion ratios," Applied Thermal Engineering, vol. 26, pp. 2272-2278, May 2006

[21] R. C. Costa and J. R. Sodre, "Compressionn ratio effects on an ethanol/gasoline fuelled engine performance," Applied Thermal Engineering, vol. 31, pp. 278-283, Sep. 2011.

[22] E. G. Giakoumis, C. D. Rakopoulos, A. M. Dimaratos, and D. C. Rakopoulos, "Exhaust emissions with ethanol or n-butanol diesel fuel blends 
during transient operation: A review," Renewable and sustainable Energy Reviews, vol. 17, pp. 170-190, Oct. 2012.

[23] M. Yao, H. Wang, Z. Zheng, and Y. Yue, "Experimental study of $\mathrm{n}$-butanol additive and multiinjection on $\mathrm{HD}$ diesel engine performance and emissions," Fuel, vol. 89, pp. 2191-2201, Apr. 2010

[24] S. S. Merola, C. Tornatre, S. E. Lannuzzi, L. Marchitto, and G. Valentino, "Combustion process investigation in high speed diesel engine fuelled with n-butanol diesel blend by conventional methods and optical diagnostics," Renewable Energy, vol. 64, pp. 225-237, Dec. 2014.

[25] A. Atmanli, E. Iteri, and B. Yuksel, "Experimental investigations of engine performance and exhaust emissions of a diesel engine fueled with diesel-nbutanol-vegetable oil blends," Energy Conversion and Mnagement, vol. 81, pp. 312-321, Mar. 2014

[26] Y.-C. Chang, W.-J. Lee, S.-L. Lin, and L.-C. Wang, "Green energy : Water-containing acetone-butanolethanol diesel blends fueled in Diesel engines," Applied Energy, vol. 109, pp. 182-191, Apr. 2013.

[27] M. Karabektas and M. Hosoz, "Performance and emission charcteristics of a diesel engine using isobutanol-diesel fuel blends," Renewable Energy, vol. 34, pp. 1554-1559, Dec. 2009.

[28] H. Liu, S. Li, Z. Zheng, J. Xu, and M. Yao, "Effects of n-butanol, 2-butanol, and methyl octynoate addition to diesel fuel on combination and emissions over a wide range of exhaust gas recirculation (EGR) rates," Applied Energy, vol. 112, pp. 246-256, Jul. 2013.

[29] O. Dogan, "The influence of $n$-butanol/diesel fuel blends utilization on a small diesel engine performance and emissions," Fuel, vol. 90, pp. 24672472, Mar. 2011. 